\title{
Parent-Child Reading: More than to Improve Children's Reading
}

\author{
Yi Huang \\ Education University of Hong Kong, Hong Kong, China \\ Email: huangyi199502@foxmail.com
}

How to cite this paper: Huang, Y. (2019) Parent-Child Reading: More than to Improve Children's Reading. Open Access Library Journal, 6: e5359.

https://doi.org/10.4236/oalib.1105359

Received: March 28, 2019

Accepted: April 9, 2019

Published: April 12, 2019

Copyright $\odot 2019$ by author(s) and Open Access Library Inc.

This work is licensed under the Creative Commons Attribution International License (CC BY 4.0).

http://creativecommons.org/licenses/by/4.0/

\begin{abstract}
Parents are the first teachers of their children in many aspects, including the language learning. Numerous studies have shown that parent-child reading can promote the language ability of children who are about to enter the reading stage. Moreover, good parent-child reading process can promote the child's social development. This paper mainly discusses how to improve the quality of parent-child reading based on the author's self-analysis and related researches.
\end{abstract}

\section{Subject Areas}

Education

\section{Keywords}

Parent-Child Reading, Language Abilities, Social Development

\section{Introduction}

When a child is very young, parents take the roles of not only caregivers, but also teachers, to teach them basic knowledge, for instance, basic language knowledge. When a baby is born, most caregivers start to talk to the baby, no matter whether he/she can understand the words. As children grow a little bit older, parents are going to promote children's reading ability. For transferring reading skills, parent-child reading is a very common method to teach reading in family education. According to the survey which focused on 2 - 3 years old children, in 2001, in the USA, for children having mothers with high school education, the percentage of children who had everyday family reading was $49 \%$. And for children whose mothers had bachelor degree, the portion was $73 \%$ (U.S. Department of Education, 2003) [1]. Of course, when I was a very little girl, my parents also 
taught me how to read through the experience of reading together. In psychology, we name the children's experiences of reading with parents together as the parent-child reading. According to previous research, when parents use the share reading style (it's also called as the dialogical style) to read with children, parent-child reading is most effective (Whitehurst, 1988) [2].

So in this essay, I would like to demonstrate the positive effects brought by parent-child reading, by telling and analyzing my own experiences. Then I would give some suggestions to parents about how to do the parent-child reading most effectively.

\section{My Experiences and Analysis for Them}

Now I am going to show you my parent-child reading experiences when I was a kid. As a whole, my family reading period can be divided into two parts-the first one is picture-book reading period, and the other is text reading period.

\subsection{Picture-Book Reading Period}

My picture-book reading period began very early. I remember that when I was about 3 years old, my parents started to teach me some simple and commonly used Chinese characters, such as sun, grass, flower, father, mother, etc., through the picture reading way. They wrote the picture book by themselves. My daddy is very good at drawing, so when I was a little girl, he drew lots of cartoon pictures for me. In each picture, he wrote the Chinese next to the image so that when he or my mother instructed, I could connect the image with its related word. This old self-made book is still on the bookshelf of my house. My parents spent lots of time with me to read this "Handmade Chinese Enlightenment Manual" at that time. According to my parents, they said I improved very fast by this way. In fact, some researches have already demonstrated the picture book can be very beneficial for young children. For instance, as in 1994, researchers found that picture book reading can help young children to expand their vocabulary significantly (Whitehurst, 1994) [3]. This study suggested that picture book is a kind of effective tool to teach children more vocabulary. Also, in 2003, some researchers only focused on children between 8 and 36 months. And this research also noted that picture book reading can help to increase children's exposure to novel vocabulary and master new concepts (Kleeck, 2003) [4]. Actually, such an early experience may have impact on the language development for a long time. Lots of longitudinal studies showed that picture book reading experience at early age could help promote literacy in preschool period (Snow, 1983; Reese, 1995; Kleeck, 2003) [4] [5] [6].

As I grow up a little bit older, about 4 or 5 years old I think, they began to buy me some short story books, such as Snow White or Mermaid. And of course, these books still were picture books. Our reading way was very interesting. Instead of that my parents pointed the picture and just read the books, they let me combine the pictures and simple sentences beside to think about what these in- 
formation meant, and then I told them the story. I didn't do very well at very beginning. There are several reasons for it.

First, I still didn't master enough Chinese words. But when I met this kind of problems, my parents never punished me, they just help. Their behaviors made me feel safe. Punishment to young children could be very harmful for mental health. It may lead to potential aggressive characteristic (Gershoff, 2002) [7]. If I learned the word before, they would use the cue to remind me. For instance, I learn the word of beautiful, but at that time I just couldn't recognize the word and didn't know the meaning. Then parents pointed the girl in the picture, and asked me "do you still remember we actually saw the word in the story of Little Mermaid? How do think the she looks like?" Then I could memorize something and knew that the word is beautiful. If I never met a word before, my parents explain this new one to me.

The second reason for I was a bad reader is that, I just read the shallow information, and I didn't try to dig out the deeper meaning, such as mental activity of the role in story. For example, I just used very brief words to explain the story, like "one day, a princess went into forest and got lost, then she met several dwarfs". My parents' solution is they helped me to expand the story. They would ask me "if you are lost in the forest, what will you feel? Will you be very scared? And now, you can guess the feeling of the little princess. Will she be frightened?" So by this way, I started to think about the role's mental state according to the his/her experience. And parents encouraged me to add these underlying content into my previous describe. Gradually, I became much better at telling stories. By the mean time, through reading story picture books with the help from parents, I expanded my vocabulary, also I started to figure out the roles' mental activities. In fact, by telling stories, by the interaction with mother and father, I also advanced my communication skills.

In my above story, my parents used the dialogical reading style in parent-child reading, and meanwhile, the processes involved a large amount of mental state languages.

What is the dialogical reading style? In fact, this style emphasizes interaction strongly. And it has three principles (Mol, 2008) [8]: "1) the use of evocative techniques by the parent that encourage the child to talk about pictured materials; 2) informative feedback by incorporating expansions, corrective modeling, and other forms that highlight differences between what the child has said and what he might have said; and 3) an adaptive parent sensitive to the child's developing abilities." Comparing to simple reading model of parents just reading story to their kid, dialogical reading is much more efficient in promoting the develop of language. By the mean time, it can reduce the risk of language and literacy impairments (Mol, 2008) [8].

Also, as mentioned, my parent-child reading experience included lots of mental state terms. Research has ever suggested that the use of mental state language in parent-child reading is good for children's theory of mind (Adrian, 2005) [9]. This study also has ever found that the frequency of words used of 
emotional terms had positive correlation with children's false belief performance. And false belief test is a common way to evaluate one's theory of mind (Shaffer, 2013) [10]. Actually, theory of mind (ToM) refers to the understanding of others' mental activity (Shaffer, 2013) [10]. The development of ToM is very important. Only when we have ToM, then can we realize other people's knowledge and perspective could be different from ours (Frith, 2005) [11]. Because of ToM, we can think of something by standing at others' point. In daily life, we usually describe the person who can think questions from others' perspective as empathetic. And both in behavioral science (Goldstein, 2012) [12] and physiological field (Völlm, 2006) [13], academics provided evidences for it too: there's a strong positive relationship between the development of ToM and empathy. Both ToM and empathy are very important for social cognition (Völlm, 2006) [13]. That means, using mental state words more can enhance kids' social cognition ability indirectly.

\subsection{Text Reading Period}

As I was about 6 years old, I entered into text reading period. They didn't select very difficult reading materials for me. However, the books did actually change. Less images and more texts are the main character of book in the new period. Also, the content changed. In the past, we did short story reading together. But when I reached the new stage, we began to read classical long stories (such as Journey to the West) and popular science articles for children (In my childhood time, the most popular one is One Hundred Thousand Why). They always selected books which were just a little bit difficult for me. And every time I met problems in reading, they would like to help me.

I think their teaching methods were right. According to SMART goal theory, we should set goals which are attainable, then we can improve (Worden, 2014) [14]. Attainable goal means that the goal should be challenging, and meanwhile we can achieve it with the efforts and helps. So it's suitable for parents and teachers to assign some missions which are beyond children's current ability. But it's worth to note that, the task cannot be too difficult. It should be accomplished with efforts and other's help. The SMART goal theory is consisting with Vigosky's theory of zone of proximal development (ZPD). However, Vigosky emphasized not only the difficulty of task but also the help from more knowledgeable persons. He considered that children acquire their culture's values, beliefs, and problem-solving strategies through collaborative dialogues with more knowledgeable members of society (Shaffer, 2013) [10]. In his theory, there's an area between young children current ability and their higher level ability. He called the area as ZPD. He thought that with the help and guidance from tutors (it's a broad conception), kids can cross the gap so that they can develop their abilities (Reber, 1995) [15]. So when you perceive that your child needs help, don't hesitate to help.

When I started my second grade in primary school, about 7 to 8 years old, my father bought a series book called General History of China. I still remember a 
very interesting process. After I finished several chapters, he didn't just let me recite the history knowledge. Instead, he drew a picture with me. He just drew a timeline on the paper firstly. After that, he let me try to remember the big events and historical figures and asked me to mark the events and figures on the timeline in chronological order. Then he encouraged me to connect the events with former one and later one. Then I realized historical events are not alone, they are interrelated. Because of my father's approach, I began to develop a systematic view of history. Since he taught me about this, I took the similar approach for reading the rest history books. When I entered into high school, I understood that the method of organizing the concepts and knowledge by drawing structural image called mind-map. Mind-map helps me a lot in all subjects. About history, even though I chose science instead of art in my high school time, I still got A in graduation examination due to foundation of my childhood. Mind mapping as a kind of reading strategies, can help children to code their knowledge and restore them in long term memory. It's benefit for stimulating kids' creativity (Wang, 2010) [16]. Besides mind mapping, parents can teach children more reading strategies, because to train children reading strategies can improve children's reading grade and academic achievement in other subjects directly or indirectly (Paris, 1986) [17].

\section{Conclusions and Suggestions}

So from my story, you can see following advantages of parent-child reading:

1) It can promote the language development,

2) It helps to develop children's the theory of mind,

3) When parent-child reading, if you teach children reading strategies, they can organize the knowledge better. And these strategies may have positive effects on other abilities.

About how to enhance parent-child reading process, my suggestions for parents are:

1) Create safe environment for parent-child reading. Please do not blame child when he/she dose not perform very well;

2) Try to use dialogical reading style more, because the style is good for language development;

3) Use the mental state words more, as this way could promote child's theory of mind;

4) Assign the slightly more difficult reading task to children. And do remember to help them when they need you;

5) When child reading ability reaches higher level, it's essential to teach them reading strategies.

\section{Limitations}

Based on the author's suggestions, dialogical reading style is the best way during parent-child reading. However, the style emphasizes the interaction between the 
parents and children very much. There are lots of other factors that can affect the quality of interaction during parent-child reading process. For example, the children's reading motivation and parents' emotion state. How to promote children's intrinsic reading motivation, how to regulate emotion for parents ... Many questions should be considered. Thus, it puts high demands on parents. It is necessary to provide some necessary guidance for parents who want to apply dialogical reading.

\section{Conflicts of Interest}

The author declares no conflicts of interest regarding the publication of this paper.

\section{References}

[1] U.S. Department of Education (2003) NCES, Early Childhood Education Program Participation Surveys of the National Household Education Surveys Program ECPP-NHES: 2001.

http://nces.edu/gov/programs/coe/2003/section6/tables/t37_1.asp

[2] Whitehurst, G.J. and Lonigan, C.J. (1998) Child Development and Emergent Literacy. Child Development, 69, 848-872.

https://doi.org/10.1111/j.1467-8624.1998.tb06247.x

[3] Whitehurst, G.J., Arnold, D.S., Epstein, J.N., Angell, A.L., Smith, M. and Fischel, J.E. (1994) A Picture Book Reading Intervention in Day Care and Home for Children from Low-Income Families. Developmental Psychology, 30, 679. https://doi.org/10.1037/0012-1649.30.5.679

[4] Anne Van Kleeck, P.H., Van Kleeck, A., Stahl, S.A. and Bauer, E.B. (2003) On Reading Books to Children: Parents and Teachers. Routledge, Abingdon-on-Thames. https://doi.org/10.4324/9781410607355

[5] Reese, E. (1995) Predicting Children's Literacy from Mother-Child Conversations. Cognitive Development, 10, 381-405. https://doi.org/10.1016/0885-2014(95)90003-9

[6] Snow, C. (1983) Literacy and Language: Relationships during the Preschool Years. Harvard Educational Review, 53, 165-189. https://doi.org/10.17763/haer.53.2.t6177w39817w2861

[7] Gershoff, E. and Eisenberg, N. (2002) Corporal Punishment by Parents and Associated Child Behaviors and Experiences: A Meta-Analytic and Theoretical Review. Psychological Bulletin, 128, 539-579. https://doi.org/10.1037/0033-2909.128.4.539

[8] Mol, S.E., Bus, A.G., De Jong, M.T. and Smeets, D.J. (2008) Added Value of Dialogic Parent-Child Book Readings: A Meta-Analysis. Early Education and Development, 19, 7-26. https://doi.org/10.1080/10409280701838603

[9] Adrian, J.E., Clemente, R.A., Villanueva, L. and Rieffe, C. (2005) Parent-Child Picture-Book Reading, Mothers' Mental State Language and Children's Theory of Mind. Journal of Child Language, 32, 673-686. https://doi.org/10.1017/S0305000905006963

[10] Shaffer, D.R. and Kipp, K. (2013) Developmental Psychology: Childhood and Adolescence. Cengage Learning.

[11] Frith, C. and Frith, U. (2005) Theory of Mind. Current Biology, 15, R644-R645. https://doi.org/10.1016/j.cub.2005.08.041

[12] Goldstein, T.R. and Winner, E. (2012) Enhancing Empathy and Theory of Mind. Journal of Cognition and Development, 13, 19-37. 
https://doi.org/10.1080/15248372.2011.573514

[13] Völlm, B.A., Taylor, A.N., Richardson, P., Corcoran, R., Stirling, J., McKie, S., Elliott, R., et al. (2006) Neuronal Correlates of Theory of Mind and Empathy: A Functional Magnetic Resonance Imaging Study in a Nonverbal Task. Neuroimage, 29, 90-98. https://doi.org/10.1016/j.neuroimage.2005.07.022

[14] Worden, J.M. (2014) An Ancalysis of Training Focused on Improving SMART Goal Setting for Specific Employee Groups. Edgewood College.

[15] Reber, A.S. (1995) The Penguin Dictionary of Psychology. Penguin Press, New York.

[16] Wang, W.C., Lee, C.C. and Chu, Y.C. (2010) A Brief Review on Developing Creative Thinking in Young Children by Mind Mapping. International Business Research, 3, 233. https://doi.org/10.5539/ibr.v3n3p233

[17] Paris, \& Oka (1986) Children's Reading Strategies, Metacognition, and Motivation. Developmental Review, 6, 25-56. https://doi.org/10.1016/0273-2297(86)90002-X 